\title{
Review of chemical research work on edible fungi in Hungary
}

\section{DEZSÖ TÖRLEY and ETELKA KOVÁCS}

\begin{abstract}
TORLEY, D. \& KOVÄCS, E. 1978: Review of chemical research work on edible fungi in Hungary. - Karstenia 18 (suppl.).

In the field of the investigation of edible fungi chemical, biological and technological research is done in Hungary. The main part of the research of the chemistry of mushrooms takes place in two institutes, the Department of Biochemistry and Food Technology of the Technical University at Budapest and the Central Food Research Institute Budapest. At the Technical University following topics have been dealt with: investigation of the carbohydrate components of mushrooms; polyacrylamide gel electrophores is of mushroom proteins and investigation of the distribution of proteins between pileus and stipe; investigation of the distribution of some enzymes in the fruiting body; investigation of enzyme activities by histochemical methods; thin layer chromatography of mushroom lipids.

in the Central Food Research Institute the preservation of mushrooms by ionizing radiation was studied and it was established that the keeping quality of the cultivated mushroom may be increased through this procedure. A pilot plant scale process was elaborated. - The favourable effect of the ionizing radiation may be explained by its influence on the hormone system and investigations have been made with plant hormones. It was stated that cytokinins influence the opening of the pileus. The greatest part of the cytokinins is to be found in the gills, but during storage this level decreases. Further research work on the cytokinins of fungi is going on.
\end{abstract}

D. Törley, Deparoment of Biochemistry and Food Technology, Technical University Budapest, Müegyetem rkp 3, H-1111 Budapest, Hungary.

E. Kovăcs, Central Food Research Institute, Herman Otto u. 15, H-1022 Budapest, Hungary.

Edible fungi are ubiquitous organisms which are known to serve as a food of value for human beings and also for domestic animals. Though the nutritional value of the fungi has been known for long time, chemical research work dealing with the chemical composition and biochemical systems of edible fungi has been done only in the last decades. This holds true of Hungary as well, where the main part of the research work on the chemistry is made in a few institutes.

At the Department of Biochemistry and Food Technology of the Technical University Budapest the following topics have been dealt with:

Investigation of the carbohydrate components of mushrooms

The soluble mono- and oligosaccharides of 70 wild growing species of edible and poisonous fungi were isolated and determined by paper chromatography. In the ethanol extract of most fungi glucose and trehalose could be detected. Mannitol and free glucosamine were found in more than $50 \%$ of the examined species. In mycorrhiza fungi relatively great amounts of xylose were detected. Mannose and galactose were present in only a small number of fungus species. The carbohydrate contents of the pileus and of the stipe may differ in the same fruiting body (Törley \& Nedelkovits 1963).

The carbohydrate components were determined also in the cultivated mushroom Agaricus bisporus. The dif- ferent carbohydrate groups were extracted successively with $80 \%$ ethanol, $10 \%$ trichloroacetic acid, $30 \%$ potassium hydroxide, I M sulphuric acid and $60 \%$ sulphuric acid, respectively. The carbohydrate content of the fractions was determined with anthron reagent, and the monosaccharides and trehalose in the extracts and in the hydrolysed solutions were identified by paper chromatography (Törley \& Nedelkovits 1965 a).

In a similar experiment the extraction of the carbohydrates was performed by following successive steps: after the removal of the lipids with petroleum ether, extraction with $80 \%$ ethanol, extraction with water, treatment with $24 \%$ potassium hydroxide, followed by treatment with conc. sulphuric acid. In the alcoholic fractions glucose, fructose, trehalose, rhamnose and mannitol, in the aqueous fractions glucose, fructose, galactose, and after hydrolysis galacturonic acid, in the alkaline solution the polysaccharide components glucose, xylose and arabinose, in the acid solution glucose, xylose, arabinose and glycosamine could be identified by paper chromatography. The determination of the carbohydrate content of the solution was made with the phenol-sulphuric acid reagent (Törley \& Nedelkovits, unpublished data).

Changes in the carbohydrate fractions of the cultivated mushroom during storage for 3 days were also investigated. It was established that at room temperature c. $30 \%$ of the carbohydrate content was 
lost, whereas at $0^{\circ} \mathrm{C}$ the carbohydrate content decreased with c. $15 \%$. The decrease was equally found in all carbchydrate fractions (Törley \& Nedelkovits 1965 b).

\section{Investigation of the fruiting body with histochemical} methods

The aim of these experiments was to study in the parts of the fruiting body the distribution of the different compounds, on the one hand, and the distribution of enzyme activities, on the other hand. Frozen sections, fixed and frozen sections, and fixed paraffin embedded sections were prepared using cryostats. The thickness of the sections varied between 5-10 micra. The distribution of the polysaccharides became visible by the use of periodic acid-'Schiff's PAS) reaction. With Hale's reaction the acidic polysaccharides were stained blue. The combined Hale and PAS reaction makes the distribution of the neutral and acidic polysaccharides visible on the same section. The localization of the nucleic acids was performed by staining with gallocyanine and potassium chromium sulphate, etc.

The distribution of enzyme activities in the cultivated mushroom $A$. bisporus was also studied. Sections were prepared from different parts of the fruiting body, i.e. from the different parts of the pileus, from the lamellae, and from different parts of the stipe. The sections were incubated with different substrates to show the activities and localization of isocitrate dehydrogenase, lactate dehydrogenase, succino dehydrogenase, citochromoxydase, esterase, acid phosphatase, alkaline phosphatase, adenosinetriphosphatase and glucose-6-phosphatase. As the result of these experiments it was stated that in the stipe the activity of the enzymes is increased in the lower part, near the mycelium. In the pileus increased enzyme activities were found below the skin and near the lamellae. The greatest activities were found in the hymenium.

Young, unripe fruiting bodies show smaller enzyme activities than the fully developed, mature ones, with the exception of several dehydrogenases.

The effect of gamma irradiation on the enzymes was also studied and it was established that gamma irradiation inactivates some metal-containing oxidoreductases. Other oxidoreductases and hydrolases are not influenced by gamma rays.

\section{Investigation of the lipid patterns of fungi}

Lipids of cultivated and wild growing mushrooms were isolated by various chromatographic technics and the lipid classes were studied with thin-layer chromatography (Törley \& Vadon-Györey 1978).

Investigation of the protein patterns of edible fungi Soluble proteins were fractionated by disc polyacrylamide gel electrophoresis, and it was established that the pherograms are characteristic for most fungus species. Certain differences could be established between the distribution of the proteins in pileus and stipe (Törley 1978).

\section{Amino acids and peptides}

Free amino acids of cultivated mushroom and of two wild growing species: Russula cyanoxantha and Leccinum scabrum were determined. The greatest part of the protein-forming amino acids occur in these fungi in the free state. The glutamic acid, aspartic acid and proline content is markedly high. $\beta$-alanine, $\gamma$-amino -butyric acid and 2,4-diaminobutyric acid were also identified.

Beneath the amino acids peptides were also isolated from some species ( $A$. bisporus, Lecoinum scabrum), occurring regularly in the fruiting bodies. Determination of the structure is in progress. At the Ceritral Food Recearch Institute in Eudapest the following research work is presently being done:

\section{Investigation of the possibility to extend the storage} life by irradiation

The storage of harvested mushrooms forms a serious problem because they are prone to rapid spoilage. Extension of the storage life of mushrooms has been the subject of investigation in many countries. In Hungary the possibility of using radiation treatment for the extension of their storage life was investigated (Kovács et al. 1968, Kovács \& Vas 1969, 1971-1971). In agreement with results of experiments abroad our investigations have shown that ionizing radiations are suitable to improve substantially the storage stability of mushrooms. The effect of irradiation depends to a large extent on the storage conditions subsequent to treatment.

It has been found under cold storage conditions ( $5^{\circ} \mathrm{C}, 70-90 \%$ rel. humidity, storage time of 13 days) that by using a $25 \mathrm{krad}$ dose the ratio of opening of the pileus could be reduced with c. 55-60\%. The effect can be increased if the radiation treatment is carried out with $100 \mathrm{krad}$ (Fig. 1). When storage is taken place at room temperature $\left(16-18^{\circ} \mathrm{C}, 65 \% \mathrm{RH}\right)$ an irradiation dose of $300 \mathrm{krad}$ is necessary. The samples given this kind of treatment can be stored for 5-6 days without loss of value, while the storability of the untreated samples is only one day.

There is a smaller loss of weight in irradiated samples than in the untreated ones. It was a general observation that irradiated mushrooms taste better than untreated ones and that the treatment had no immediate effect on the colour, odour, flavour or texture of the mushrooms. Radiation treatment is immediately followed by a slight brownish discolouration which, however, does not increase on further storage, in contrast to the intensive browning of non-irradiated controls. The tendency to browning is observed mainly when irradiation is carried out with an electron accelerator or at room temperature. Ionizing radiation did not cause deterioration of the organoleptic properties of the mushrooms, on the contrary it promoted preservation of aroma and flavour. 
Fig. 1. Effect of ionizing radiation on the preservation of Agaricus bisporus at $5^{\circ} \mathrm{C}(70-90 \%$ $\mathrm{RH}$, storage time of 13 days). $\mathrm{Co}^{60} \gamma$ source $(0,25,100$ and $300 \mathrm{krad})$.

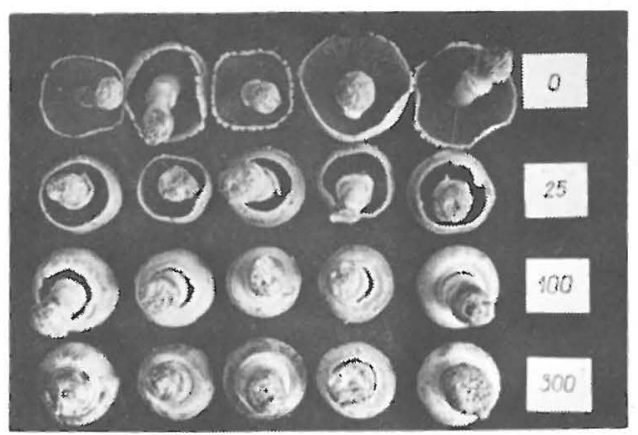

So far the quality of mushrooms has been established by morphological and sensory methods.

\section{Investigation of substances that affect the growth}

\section{of mushrooms}

At present the biology of mushrooms in the post -harvest period is being studied. Hormonal control is the subject of investigations.

Substances affecting the growth of mushrooms have not been sufficiently investigated. It was noted already at the beginning of the century that the pileus contained one or more substances which affected the growth of the stipe. These substances were not found to be identical with the auxin-type substances in higher plants.

Although auxin was found to be present in the gills as well, this was not, however, responsible for the growth of mushrooms. Frobably ripening of the mashroom and the opening of the pileus is determined by the mutual effect of hormones, and with knowledge of this mutual effect light will be thrown on the role of auxins.

The cytokinins are mainly responsible for the inhibition of aging of plants. The question arises whether cytokinins are present in mushrooms and how the opening of the cap is affected by them. Miller (1967) and Crafts \& Miller (1974) reported having detected zeatin and zeatin riboside in various mushroom varioties. This cytokinin activity was determined by soya callus test.

The method of Letham \& Williams (1969) was used to extract cytokinin from $A$, bisporus. In the course of the thin-layer chromatographic qualitative analysis zeatin and $\mathrm{N}^{6}$-dimethylallyladenine (DMAA) were identified.

The flesh and the gills were examined separately and it was found that the change as a function of storage time occurred mainly in the gills. Therefore in subsequent experiments gills were mostly used. Mushrooms freshly picked were treated with the extract of gills in the following manner: on a tray containing $500 \mathrm{ml}$ of gill extract 15 mushrooms were placed with their stipe immersed $1 \mathrm{~cm}$ deep into the extract. The tray was placed in a thermostat of $19-20^{\circ}$ C temperature and 97-99\% RH. The mushrooms were incubated for $25-40 \mathrm{~h}$ and during this time the diameter of the pileus, the opening formed and the height of the whole body were regularly measured.

Fig. 2 shows the frequency distribution of openings at four different points of time. The concentration of the extract changed from 3 to $60 \mathrm{~g} / \mathrm{l}$. The opening is understood to mean the distance between the stipe and the edge of the pileus. The opening was expressed as percentage of the initial diameter of the pileus. Twenty to sixty mushrooms were measured in each experiment and the average of three experiments is illustrated in the figure. A significant difference was observed in the frequency distributions as obtained at the four points of time with mushroom extracts of different concentrations. Evaluation was carriéd out by multi-sample $x^{2}$-test.It was established that mushroom extracts prepared from 30-60 g gills per litre inhibited substantially the opening of mushroom pilei.

On the basis of preliminary experiments four characteristic opening ranges were established:

- group a contained mushrooms with closed pileus;

- group B consisted of mushrooms with 11-21\% opening, corresponding to $4.1-8 \mathrm{~mm}$ distance;

- group C consisted of mushrooms with 22-28\% opening, corresponding to $8.1-12 \mathrm{~mm}$ distance;

- group D consisted of mushrooms with 29-38\% opening, corresponding to $12.1-16 \mathrm{~mm}$ distance (Fig. 2).

Fig. 3 shows the distribution of mushrooms according to the four groups as a function of storage time. Diagram A shows the frequency of mushrooms with closed pileus as a function of time. It can be seen that the opening is a function of the concentration of the extract. In graphs $B$ and $C$ the frequency of openings is nearly constant, while in graph $D$ the frequency increases significantly with the observation period. (Opening inhibiting extract concentrations form exceptions).

In Fig. 4 the influence of mushroom extracts of different concentrations upon the opening of the pileus, is illustrated. Opening ranges were grouped according to groups A, B, C and D, as described above. Measurements were carried out after incubation periods of 20 and $42.5 \mathrm{~h}$. The fact that the pilei are influenced according to the optimum curve points to hormonal control (Fig. 4).

Since the pileus openings were strongly inhibited by the gill extracts it seemed desirable to purify the extract in order to be able to detect its chemical composition. 
Fig. 2. Frequency distribution of openings at four different points of time $(A, B, C, D$ are characterictic opening regions; $0,11-21$, $22-28$ and $29-38 \%)$. $* \mathbf{x} \mathbf{x}=$ very highly significant difference.

\section{BUTANOLIG PHASE}

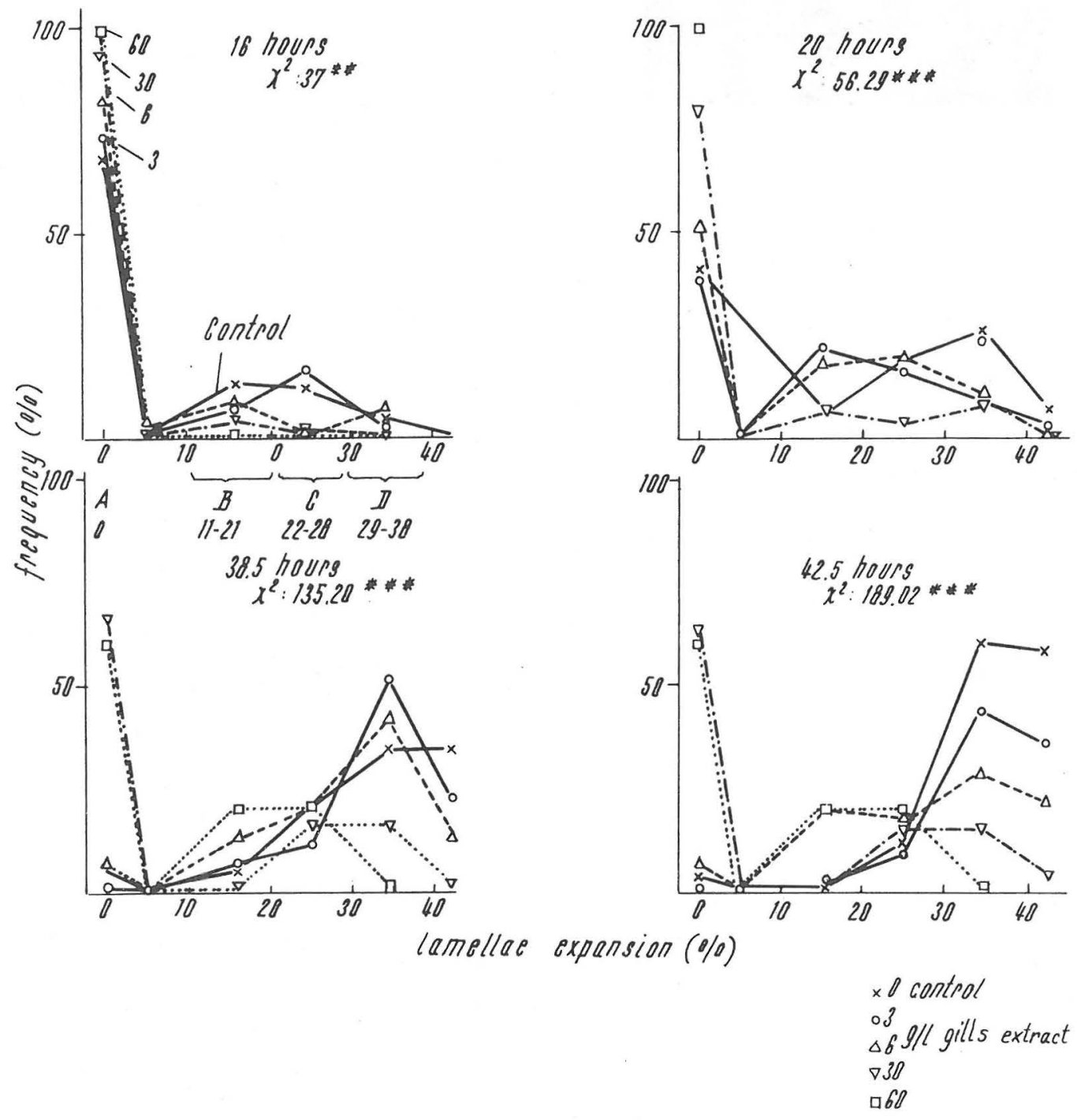


Fig. 3. Distribution of mushrooms according to the four groups as a function of storage time

( A, B, C, D are characteristic opening

regions, cf. Fig. 3 ).

\section{BUTANOLIG PHASE}
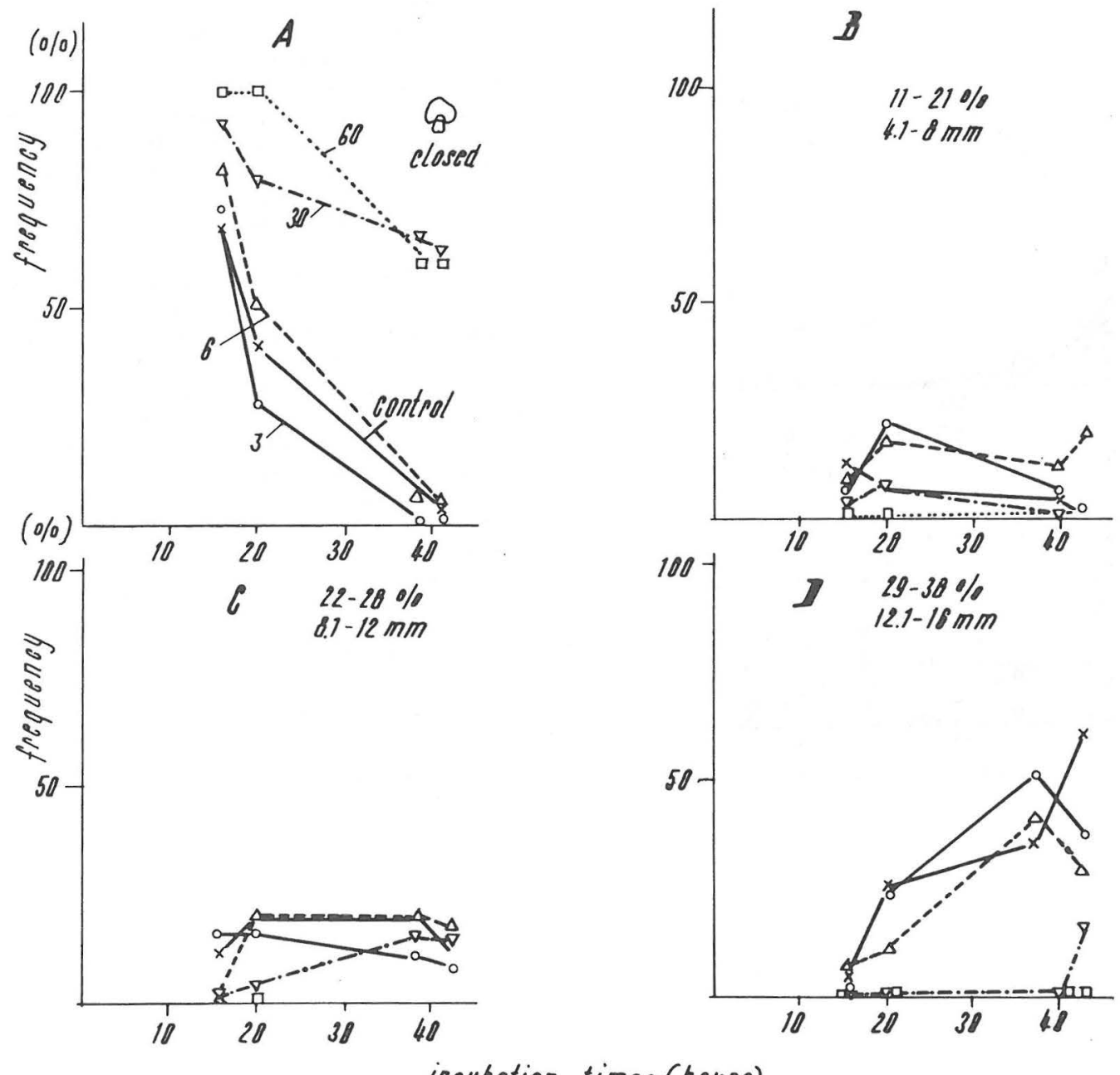

incubation timbs (houns) 
Fig. 4. Influence of mushroom extracts of different concentrations upon the opening of the pileus ( $A, B, C$ and $D$ are characteristic opening regions, cf. Fig. 3).
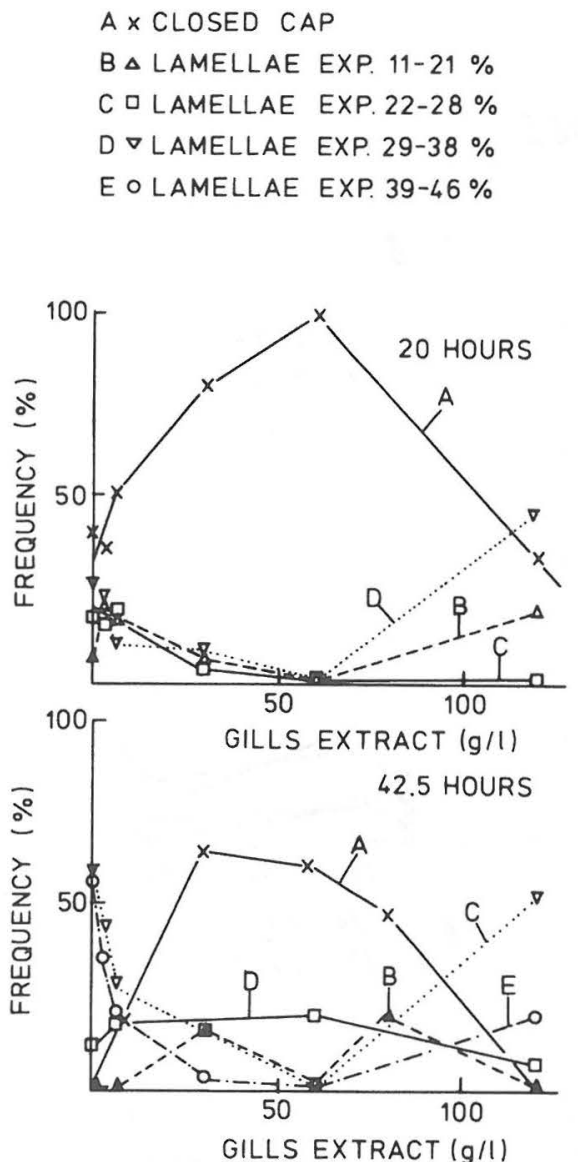

\section{References}

Crafts, C. B. \& Miller, C. O. 1974: Detection and identification of cytokinins produced by mycorrhizal fungi. - Plant Physiol. 54: 586588 .

Kovács, E. \& Vas, K. 1970: Ionizáló sugárzások alkalmazása a friss csiperkegomba eltarthatóságának növelésére. (Application of ionizing radiations to extend the shelf life of cultured mushrooms). - "Preservation of food and drug products and sterilization of medical instruments by ionizing radiation", Conference, Budapest, 24-26 March.

-" 1974: Effect of ionizing radiations on some organoleptic characteristics of edible mushroom, - Acta Alimentaria 3 (1): 11-17.

Kovács, E., Vas, K. \& Farkas, J. 1968a: A termesztett csiperkegomba eltarthatósági idejének növelése ionizálo sugárzással. (Prolongation of shelf life of cultured mushrooms by ionizing radiation). - Atomtechnikai Tajékoztat6 7 : 349-354.

-"- 1968b: Kisérletek a csiperkegomba eltarthatósági idejének növelésére ionizáó sugárzással. (Experiments on prolonging the storage life of cultured mushrooms by ionizing radiation). - Kisérletügyi Közlemenyek LXI/F. (1-3): 3-17.

Letham, D. S. \& Williams, M. W. 1969: Regulators of cell division in plant tissues. VIII. The cytokinins of the apple fruit. - Physiol. Plant. 22: 925-936.

Miller, C. 0. 1967: Zeatin és zeatin riboside from a Mycorrhizal fungus. - Science 157: 1055-1056.

Törley, D. 1978: Protein patterns of edible fungi. - Karstenia 18 (suppl.). (This issue).

Törley, D. \& Nedelkovits, J. 1963:-Élelmiszervizsg. Közl. 9: 309.

-"- 1965a: - Élelmiszervizsg. Közl. 11: 199.

-"- 1965b: - Élelmiszervizsg. Közl. 11: 257.

Törley, D. \& Vadon-Györey, E. 1978: Lipid patterns of edible fungi. - Karstenia 18 (suppl.). (This issue). 